Prepared for the U.S. Department of Energy under Contract DE-AC05-76RL01830

\title{
Fast Pyrolysis and Hydrotreating: 2013 State of Technology R\&D and Projections to 2017
}

SB Jones

LJ Snowden-Swan

PA Meyer

AH Zacher

MV Olarte

C Drennan

March 2014 


\title{
DISCLAIMER
}

This report was prepared as an account of work sponsored by an agency of the United States Government. Neither the United States Government nor any agency thereof, nor Battelle Memorial Institute, nor any of their employees, makes any warranty, express or implied, or assumes any legal liability or responsibility for the accuracy, completeness, or usefulness of any information, apparatus, product, or process disclosed, or represents that its use would not infringe privately owned rights. Reference herein to any specific commercial product, process, or service by trade name, trademark, manufacturer, or otherwise does not necessarily constitute or imply its endorsement, recommendation, or favoring by the United States Government or any agency thereof, or Battelle Memorial Institute. The views and opinions of authors expressed herein do not necessarily state or reflect those of the United States Government or any agency thereof.

\author{
PACIFIC NORTHWEST NATIONAL LABORATORY \\ operated by \\ BATTELLE \\ for the \\ UNITED STATES DEPARTMENT OF ENERGY \\ under Contract DE-AC05-76RL01830 \\ Printed in the United States of America \\ Available to DOE and DOE contractors from the \\ Office of Scientific and Technical Information, \\ P.O. Box 62, Oak Ridge, TN 37831-0062; \\ ph: (865) 576-8401 \\ fax: $(865) 576-5728$ \\ email: reports@adonis.osti.gov

\footnotetext{
Available to the public from the National Technical Information Service,

U.S. Department of Commerce, 5285 Port Royal Rd., Springfield, VA 22161

ph: (800) 553-6847

fax: (703) 605-6900

email: orders@ntis.fedworld.gov

online ordering: http://www.ntis.gov/ordering.htm
}

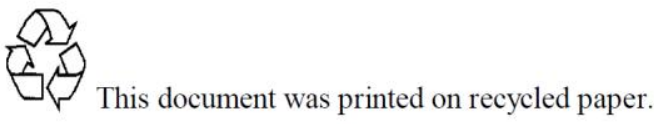




\title{
Fast Pyrolysis and Hydrotreating: 2013 State of Technology R\&D and Projections to 2017
}

\author{
SB Jones \\ LJ Snowden-Swan \\ PA Meyer \\ $\mathrm{AH}$ Zacher \\ MV Olarte \\ C Drennan
}

March 2014

Prepared for

the U.S. Department of Energy

under Contract DE-AC05-76RL01830

Pacific Northwest National Laboratory

Richland, Washington 99352 



\section{Contents}

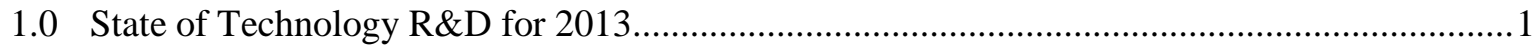

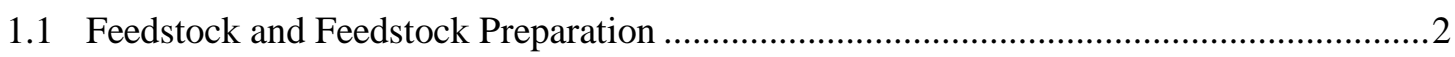

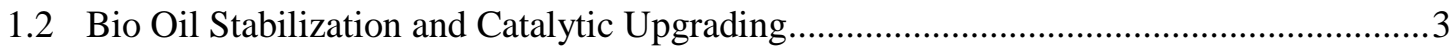

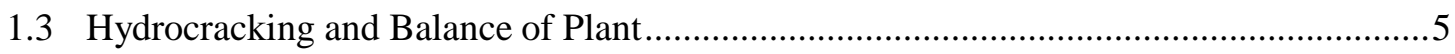

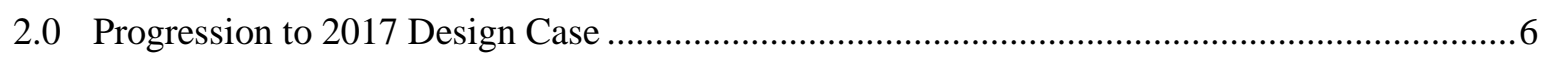

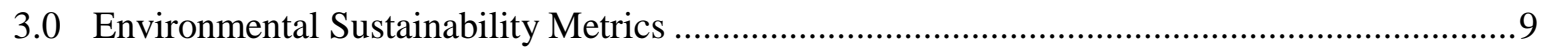

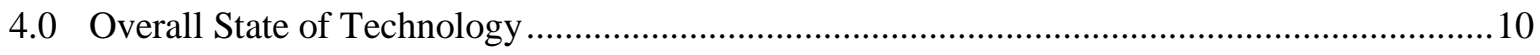

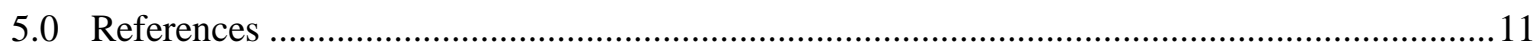

Appendix A - Methodology for GHG and Fossil Energy Calculations ....................................... 12

\section{Figures}

Figure 1. Block Flow Process Diagram ...................................................................................2

Figure 2. Plot of Upgraded Oil Oxygen Content and Specific Gravity as a Function of Time on

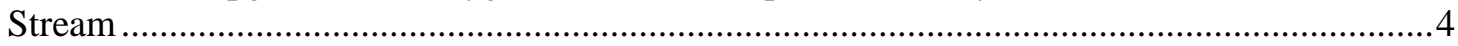

Figure 3. Plot of Product Splits as a Function of Time on Stream....................................................5

Figure 4. Conversion Cost Progression Based on 2013 Design Case ..............................................

\section{Tables}

Table 1. SOT and Projections Based on 2013 Design Case ....................................................... 8

Table 2. Sustainability Metrics for Fast Pyrolysis and Upgrading Conversion .............................. 9 



\subsection{State of Technology R\&D for $\mathbf{2 0 1 3}$}

The overarching strategic goal of the DOE Bioenergy Technologies Office (BETO) "is to develop commercially viable biomass utilization technologies to enable the sustainable, nationwide production of biofuels that are compatible with today's transportation infrastructure and can displace a share of petroleum-derived fuels to reduce U.S. dependence on oil and encourage the creation of a new domestic bioenergy industry" (US DOE, 2013). The Conversion R\&D technical element of the Office supports research and development (R\&D) toward this end via a performance goal to "make cellulosic biofuels competitive with petroleum-based fuels at a modeled cost of mature technology of \$3/gallon gasoline equivalent (\$2011), based on EIA projected wholesale prices in 2017" (US DOE, 2013). Annual cost targets toward meeting the 2017 performance goal are projected based on modeled scenarios of technical achievements that may be possible in the near-term.

Modeled scenarios, in close collaboration with researchers, are used to perform conceptual evaluations termed "design cases". These provide a detailed basis for understanding the potential of conversion technologies and help identify technical barriers where research and development could potentially lead to significant cost improvements. There are two design cases for fast pyrolysis and catalytic upgrading to hydrocarbon fuels. First is the 2009 "Production of Gasoline and Diesel from Biomass via Fast Pyrolysis, Hydrotreating and Hydrocracking: A Design Case" (Jones et al. 2009). This report is based on the relatively small amount of literature available at the time, particularly for the catalytic upgrading of fast pyrolysis oil and the capital costs associated with fast pyrolysis. An updated design case, "Process Design and Economics for the Conversion of Lignocellulosic Biomass to Hydrocarbon Fuels: Fast Pyrolysis and Hydrotreating Bio-oil Pathway" (Jones et al. 2013), captures a better understanding of the capital and operating costs from BETO's research and development efforts as well as published values for capital expenditures associated with fast pyrolysis.

Each year, BETO assesses their research progress towards annual technical targets, by incorporating data from their R\&D portfolio into technoeconomic models. Published data are also incorporated, where available, to capture the current state of the art for a given technology. The state of technology R\&D, also known as the state of technology (SOT), model and accompanying report reflect the minimum fuel selling price (MFSP) for the technology, modeled as an $\mathrm{n}^{\text {th }}$ plant ${ }^{1}$ obtaining a $10 \%$ internal rate of return at a net present value of zero. Economic assumptions are consistent across BETO design cases and SOTs, to allow standardization of an economic basis for technology comparisons ${ }^{2}$. This standardization does not account for differing levels of maturity amongst technologies under investigation, thus SOTs play an important role in documenting current thinking about data gaps and research needs. New projections for annual cost targets are then developed and documented as a reference for BETO's Multi-Year Program Plan (MYPP). Finally, the SOT captures the current state of sustainability indicators, based on modeled inputs and outputs for the technology in the context of an $n^{\text {th }}$ plant design, including greenhouse gas (GHG) emissions, fossil energy consumption, total fuel yield per ton of biomass, carbon-to-fuel efficiency, water consumption, and wastewater generation.

\footnotetext{
1 " $\mathrm{n}$ "th" plant design assumptions do not account for additional first of a kind plant costs, including special financing, equipment redundancies, large contingencies and longer startup times necessary for the first few plants. For $n^{\text {th }}$ plant designs, it is assumed that the costs reflect a future time when the technology is mature and several plants have already been built and are operating.

${ }^{2}$ Current and historical economic assumptions may be found in Appendix C of BETO's Multi-Year Program Plan (US DOE 2013).
} 
This report documents the current SOT for fast pyrolysis and bio oil catalytic upgrading to gasoline and diesel blendstocks for 2013. The process model is based on the two design cases, state of technology reports for 2011 (Jones and Male, 2012) and 2012 (Jones and Snowden-Swan, 2013), and developments in catalytic upgrading after 2012. This report also provides the basis for cost target projections through 2017.

A box flow diagram for fast pyrolysis followed by catalytic bio oil upgrading to gasoline and diesel blendstocks is shown in Figure 1. The process comprises fast pyrolysis of woody biomass, stabilization of fast pyrolysis oil, two-stage hydrotreating, product separation, and hydrocracking of diesel (and heavier than diesel) to increase the yield of transportation fuels. The following sections capture the SOT for each stage of the process.

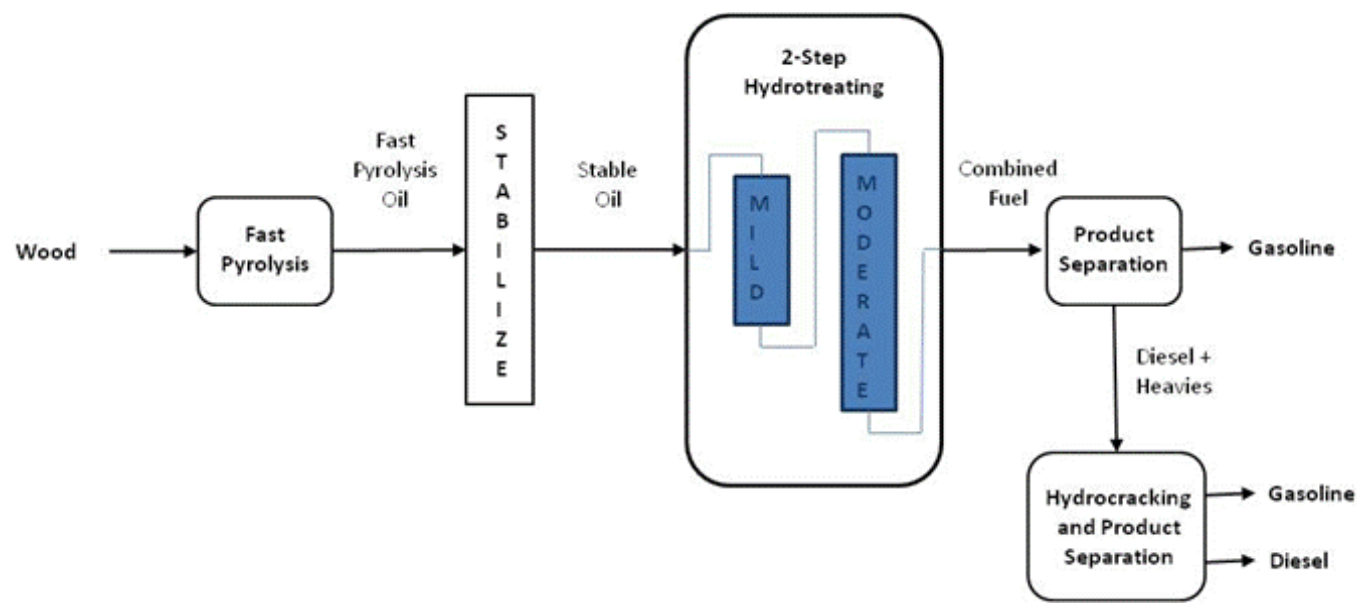

Figure 1. Block Flow Process Diagram

\subsection{Feedstock and Feedstock Preparation}

INL has made significant advances in understanding feedstock preparation and its associated costs. The feedstock cost of $\$ 102.12$ dry ton biomass is based on costs for low-ash pine that is pre-processed to pyrolysis reactor throat-ready. This entails feedstock drying from $30 \%$ moisture to $10 \%$ moisture and grinding to 2-6 mm particles. Details of feedstock logistics, handling, and drying are described in the 2013 design case update for fast pyrolysis and upgrading to hydrocarbons as well as in the Feedstock Supply System Design and Economics for Conversion of Lignocellulosic Biomass to Hydrocarbon Fuels: The 2017 Design Case (INL 2014). Feedstock behavior during conversion, both in fast pyrolysis and in subsequent catalytic upgrading, is currently under evaluation to determine the effects of ash composition on the overall process.

\subsection{Fast Pyrolysis}

Fast pyrolysis entails rapid heating of biomass feedstock to approximately $932^{\circ} \mathrm{F}\left(500^{\circ} \mathrm{C}\right)$ in less than two seconds, and at atmospheric pressure. Pyrolysis vapors are rapidly quenched and captured. Cooled pyrolysis products comprise primarily liquid (water and organic compounds), char mixed with biomass 
ash, and non-condensable gases. Conventional ${ }^{3}$ fast pyrolysis is already commercialized for production of food flavorings and power.

This SOT, like the 2013 updated design case, assumes two 1000 dry metric tpd pyrolyzers operating in parallel. This is a change from the 2009 design case where a single pyrolyzer was assumed. The change in assumption from a single large unit to two smaller parallel units was motivated by the potential for heat transfer limitations which may make this degree of scale-up difficult to achieve. Also included in the 2013 updated design case is an increase in assumed yield of pyrolysis oil from $60 \mathrm{wt} \%$ organic material (on a dry wood basis) to $62 \mathrm{wt} \%$. This assumed yield improvement is based on recently published data for small-scale pyrolysis ( $1-20 \mathrm{~kg} / \mathrm{h}$ ) operating on low-ash pine feedstock (VTT 2012). The effects of blended feedstocks (which may be used in future design cases and SOTs), in addition to the effects of ash (noted above) are currently being explored to inform future technoeconomic efforts.

\subsection{Bio Oil Stabilization and Catalytic Upgrading}

Hydrotreating removes oxygen, nitrogen, and sulfur and saturates olefins and aromatics. Upgrading fast pyrolysis oil to stable hydrocarbon oil occurs in three catalytic steps, both for the 2013 SOT experimental work reported on here and for the target (design) case projected to be achievable in 2017. The first catalytic reactor assumes a ruthenium based catalyst and uses very mild hydrotreating conditions of 1400 psig, $284^{\circ} \mathrm{F}\left(140{ }^{\circ} \mathrm{C}\right)$, and 0.5 liquid hourly space velocity (LHSV) to remove the most reactive species assumed to cause fouling in downstream beds. This is followed by a second catalytic reactor assumed to operate at $2000 \mathrm{psig}, 349^{\circ} \mathrm{F}\left(176^{\circ} \mathrm{C}\right)$, and $0.22 \mathrm{LHSV}$. Here again, a ruthenium based catalyst is assumed to eliminate reactive species that will cause catalyst deactivation in the last bed. The final bed assumes use of a molybdenum based catalyst and operates at more severe conditions of $2000 \mathrm{psig}, 770{ }^{\circ} \mathrm{F}(410$ ${ }^{\circ} \mathrm{C}$ ), and 0.22 LHSV. This sequence reduces the oxygen content of the raw pyrolysis oil to less than 2 $\mathrm{wt} \%$ in the oil leaving the final reactor, and is based on data from reactors ranging in scale from $30 \mathrm{~mL}$ to $400 \mathrm{~mL}$.

Some research efforts in 2013 focused on gaining a better understanding of catalyst fouling mechanisms and catalyst deactivation. Other research efforts focused on leveraging those understandings to develop novel catalyst systems. Technoeconomic analysis also directed research towards maximizing the amount of time on stream before the catalysts in the second and third beds require complete replacement. Catalyst deactivation currently results in short on-stream times before some portion of the catalyst has to be replaced. In its various forms, catalyst deactivation results in a loss of both the hydrodeoxygenation (HDO) functionality and the cracking functionality, resulting in higher residual oxygen content in the product, increased boiling range, and higher product density. Therefore, 2013 research also focused on typical catalyst maintenance issues which include coking that leads to physical plugging, catalyst deactivation, and exotherm control.

The ability to extend time on stream of the hydrotreating catalyst from 30 hours in 2012 to 60 hours in 2013 is solely related to better understanding of utilizing operating conditions (e.g., temperature, pressure, LHSV) to manage exotherms, resulting in a reduced catalyst deactivation rate. Figure 2 shows density, oxygen content, and oil yield as a function of time on stream for the extended runs. These runs were

\footnotetext{
${ }^{3}$ Fast pyrolysis may be done in the presence of catalysts or, in another variation pyrolysis vapors may be passed over catalysts prior to condensation. "Conventional" denotes that the fast pyrolysis is non-catalytic.
} 
executed at the $400 \mathrm{~mL}$ scale, at PNNL. The first 700 hours on this catalyst was achieved during continuous runs during multiple separate campaigns of roughly five days each. After each run the reactor was idled to allow time for analysis of results. The effect of multiple starts and stops resulted in the saw tooth effect shown during the 0-700 hour time frame in Figure 2.

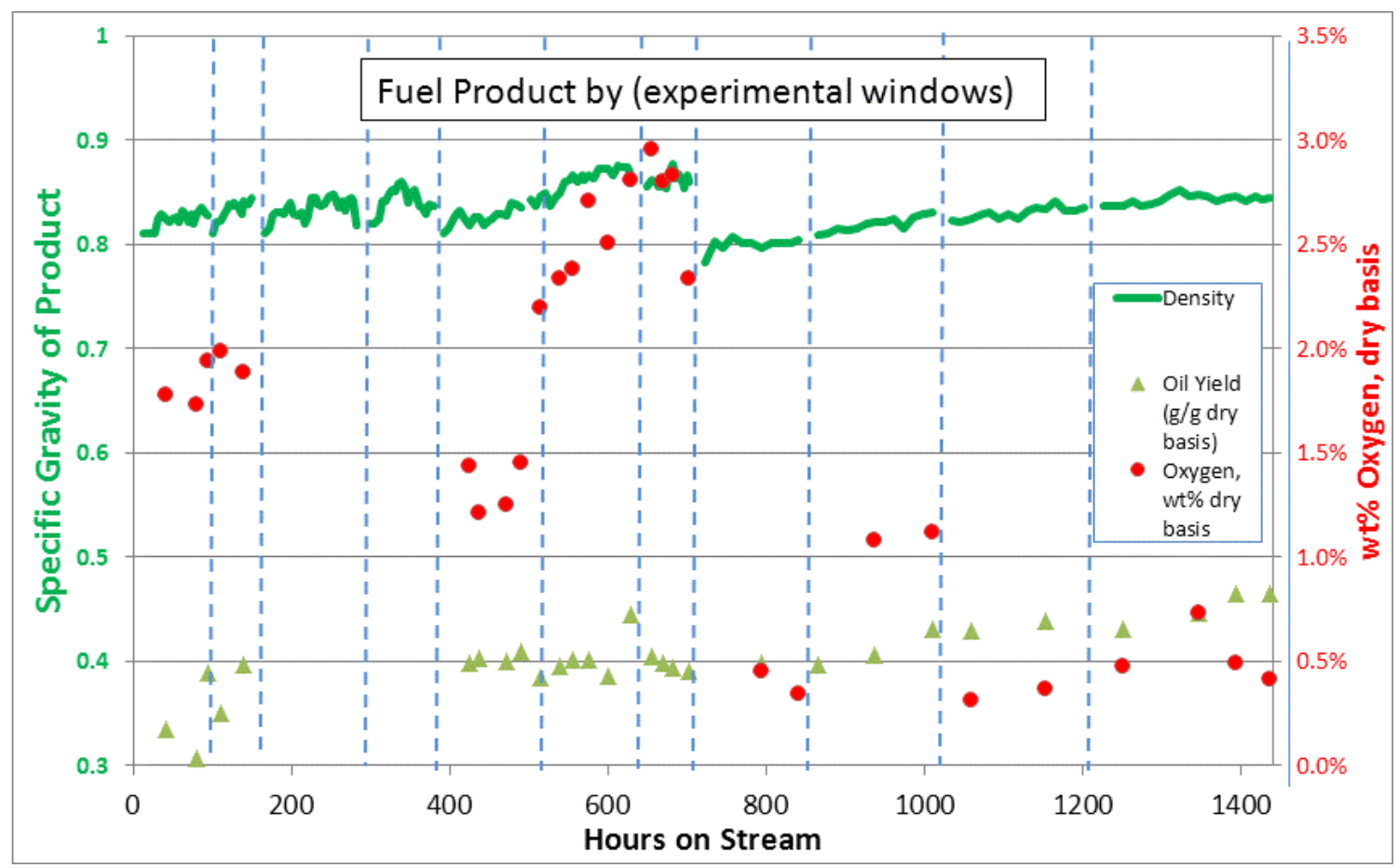

Figure 2. Plot of Upgraded Oil Oxygen Content and Specific Gravity as a Function of Time on Stream

In order to explore a wider set of conditions and product quality as well as understand the impact of the start/stop cycles, the next campaign was performed continuously putting an additional 740 hours on the hydrocracking catalyst without pause (time frame from 700-1440 hours). Operating conditions were varied during that time to understand the impact of residence time and temperature, as well as determine the impact of exotherm control on catalyst maintenance, performance, and product quality. This was done by slowing the space velocity to low rates (that would not be used commercially) to prevent large spikes in temperatures. Commercially, exotherm control would use industrial methods similar to that used for conventional hydrotreaters that experience large heat releases, such as hydrocrackers. This would be done through cold hydrogen injection at multiple points along the length of the catalyst bed. However, this allowed understanding of the temperature requirements (bulk and exotherm) needed to prevent catalyst damage while still achieving the desired degree of deoxygenation. Overall, 1440 hours on the original catalyst charge was achieved. Figure 3 shows that the product distribution remained fairly steady throughout the runs. 


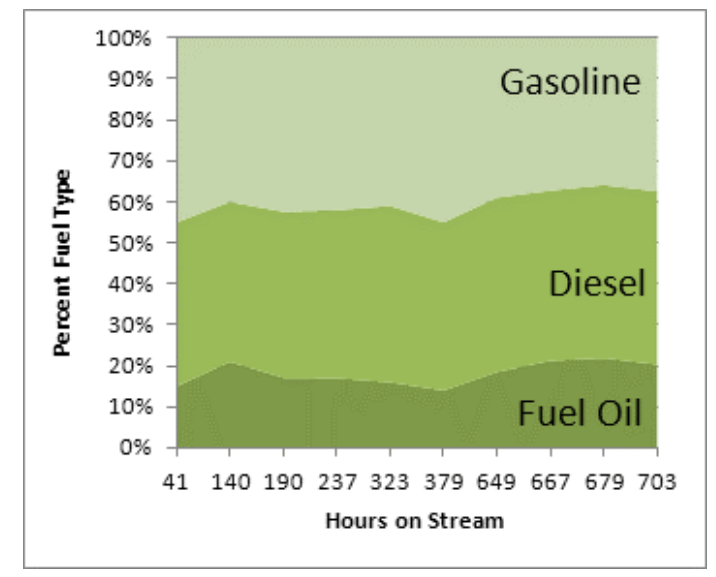

Figure 3. Plot of Product Splits as a Function of Time on Stream

The key research areas for conventional fast pyrolysis oil upgrading are catalyst life and product quality. The key results contributing to the 2013 SOT are:

- Understanding operating conditions for the catalysts that enable longer catalyst life,

- Demonstrated extended catalyst lifetime from 30 to 60 days for the hydrodeoxygenation and hydrocracking of bio-oils to liquid fuel, and

- Improved oil yield to 0.44 grams oil per gram of pyrolysis oil (dry basis) through exotherm control and operating at lower final temperature while still producing a low oxygen fuel.

\subsection{Hydrocracking and Balance of Plant}

Hydrocracking creates smaller chain components from larger ones and saturates alkenes and aromatics. It also removes any remaining oxygenates, such as phenolic groups which appear to be the most difficult oxygenate type to remove. The 2013 SOT case assumes that all of the diesel and heavier boiling range product may be finished in a hydrocracker. This treatment cracks the heavier-than-diesel components back to the diesel range and removes residual olefins and oxygenates and saturates some of the aromatics. No data have been published in this area as of 2013, and research has not been conducted in this area in support of this SOT.

The main contributor to the balance of plant costs is from hydrogen generation via conventional natural gas steam reforming. It is assumed that off-gases from the fast pyrolysis reactor and from the hydrotreaters can be used in the hydrogen plant. Verification of this assumption was not conducted in 2013 in support of this SOT, and may require future work. 


\subsection{Progression to 2017 Design Case}

In order to be on a trajectory toward the 2017 design case, reduced capital and operating costs associated with the upgrading catalyst are needed. Specifically:

- Increased liquid hourly space velocity to improve catalyst use and reduce reactor capital, as this sets the reactor size. Associated with this is the weight hourly space velocity, which sets the amount of catalyst fill needed.

- Reduced replacement costs for the the stabilizer and the first upgrader catalysts. Both beds use a carbon supported catalyst at $7.8 \mathrm{wt} \%$ ruthenium loading. There is room for substantial cost reduction through lower ruthenium loadings and/or less expensive metals and catalyst supports, particularly those amenable to typical regeneration methods.

- Increased time on stream before a complete catalyst change is needed. This eliminates the need for hot spare reactors. Catalyst regeneration methods are one way to mitigate short catalyst life.

- Improvements in both the total upgraded product and individual fuel products characterization to better understand upgrading effectiveness.

- Implementation, if possible, of the use of hydrocracking catalyst to derive additional fuel from the heavier than diesel cut from the upgraders and to estimate the extent that the diesel cut requires aromatic saturation to achieve cetane specifications.

There are a number of ways to achieve the modeled 2017 cost goals. Table 2 and Figure 4 show the progression towards the 2017 target. The projected conversion costs for FY14 - FY16 are:

- FY14 is $\$ 4.09$ /gge, based on a $22 \%$ decrease in costs associated with the upgrading catalysis processes over the 2013 SOT

- FY15 is $\$ 3.69 /$ gge, based on a $20 \%$ decrease in costs associated with the upgrading catalysis processes over the 2014 SOT

- FY16 is $\$ 3.01 /$ gge, based on a $47 \%$ reduction in upgrading and finishing processing costs over the 2015 SOT

- The modeled conversion cost projections will be achieved through a combination of optimized space velocity, catalyst metal type and loading and catalyst regeneration. 


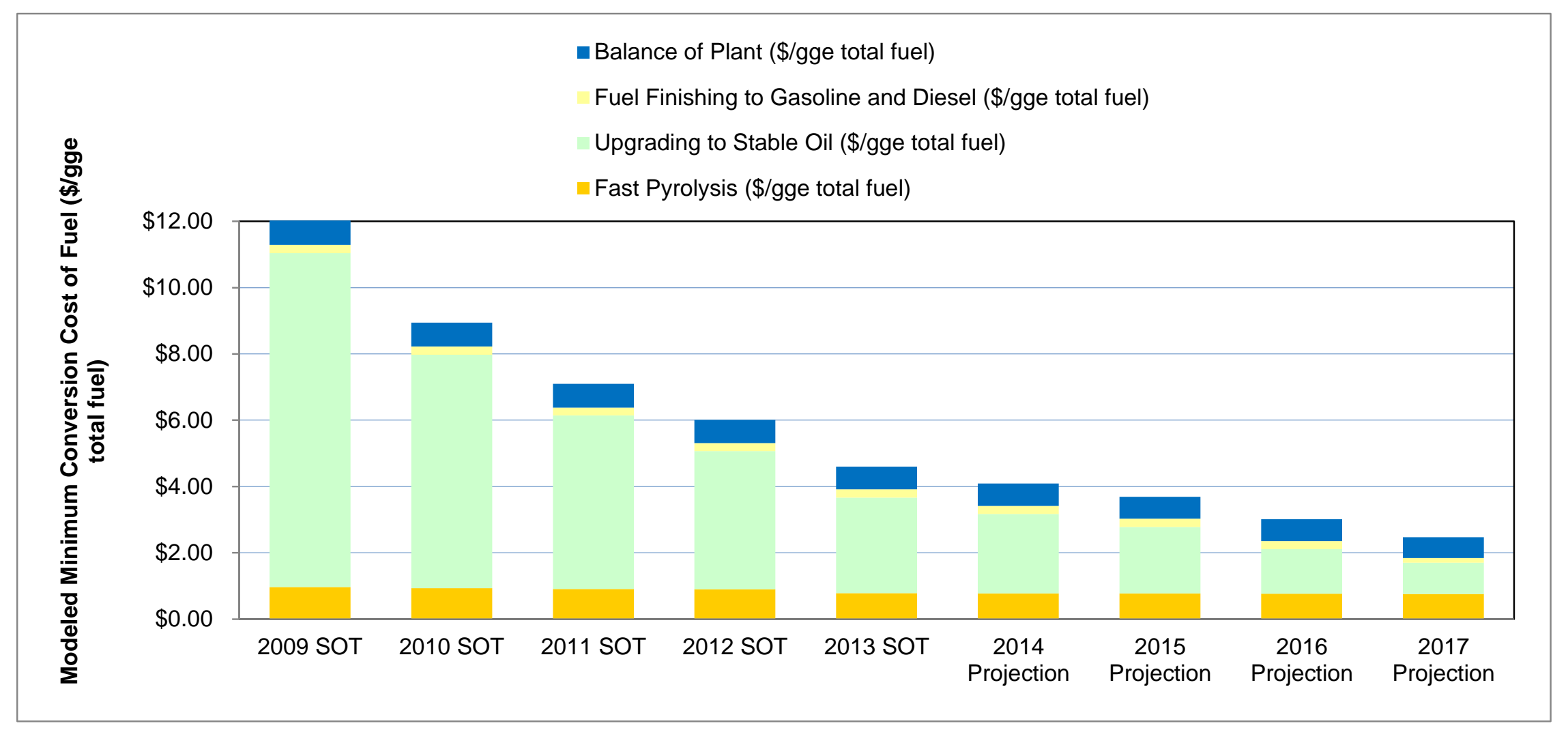

Figure 4. Conversion Cost Progression Based on 2013 Design Case 
Table 1. SOT and Projections Based on 2013 Design Case

\begin{tabular}{|c|c|c|c|c|c|c|c|c|c|c|}
\hline $\begin{array}{l}\text { Processing Area Cost Contributions } \\
\text { \& Key Technical Parameters }\end{array}$ & Metric & 2009 SOT & 2010 SOT & 2011 SOT & 2012 SOT & 2013 SOT & $\begin{array}{c}2014 \\
\text { Projected }\end{array}$ & $\begin{array}{c}2015 \\
\text { Projected }\end{array}$ & $\begin{array}{l}2016 \\
\text { Projected }\end{array}$ & $\begin{array}{c}2017 \\
\text { Projected }\end{array}$ \\
\hline \multirow{2}{*}{ Conversion Contribution } & \$/gal gasoline blendstock & $\$ 12.40$ & $\$ 9.22$ & $\$ 7.32$ & $\$ 6.20$ & $\$ 4.51$ & $\$ 4.02$ & $\$ 3.63$ & $\$ 2.96$ & $\$ 2.44$ \\
\hline & $\$$ /gal diesel blendstock & $\$ 13.03$ & $\$ 9.69$ & $\$ 7.69$ & $\$ 6.52$ & $\$ 5.01$ & $\$ 4.46$ & $\$ 4.03$ & $\$ 3.29$ & $\$ 2.70$ \\
\hline $\begin{array}{l}\text { Conversion Contribution, Combined } \\
\text { Blendstocks }\end{array}$ & $\$ / G G E$ & $\$ 12.02$ & $\$ 8.94$ & $\$ 7.10$ & $\$ 6.02$ & $\$ 4.60$ & $\$ 4.09$ & $\$ 3.69$ & $\$ 3.01$ & $\$ 2.47$ \\
\hline Perfomance Goal & $\$ /$ GGE & & & & & & & & & $\$ 3$ \\
\hline Combined Fuel Selling Price & $\$ /$ GGE & $\$ 13.40$ & $\$ 10.27$ & $\$ 8.26$ & $\$ 7.04$ & $\$ 5.77$ & $\$ 5.26$ & $\$ 4.75$ & $\$ 4.01$ & $\$ 3.39$ \\
\hline Production Gasoline Blendstock & $\mathrm{mm}$ gallons $/ \mathrm{yr}$ & 30 & 30 & 30 & 30 & 29 & 29 & 29 & 29 & 29 \\
\hline Production Diesel Blendstock & $\mathrm{mm}$ gallons/yr & 23 & 23 & 23 & 23 & 32 & 32 & 32 & 32 & 32 \\
\hline Yield Combined Blendstocks & GGE/dry US ton & 78 & 78 & 78 & 78 & 87 & 87 & 87 & 87 & 87 \\
\hline Yield Combined Blendstocks & mmBTU/dry US ton & 9 & 9 & 9 & 9 & 10 & 10 & 10 & 10 & 10 \\
\hline Natural Gas Usage & scf/dry US ton & 1,115 & 1,115 & 1,115 & 1,115 & 1,685 & 1,685 & 1,685 & 1,685 & 1,685 \\
\hline \multicolumn{11}{|l|}{ Feedstock } \\
\hline Total Cost Contribution & $\$ /$ gge fuel & $\$ 1.38$ & $\$ 1.33$ & $\$ 1.17$ & $\$ 1.03$ & $\$ 1.17$ & $\$ 1.16$ & $\$ 1.06$ & $\$ 0.99$ & $\$ 0.92$ \\
\hline Capital Cost Contribution & $\$$ /gge fuel & $\$ 0.00$ & $\$ 0.00$ & $\$ 0.00$ & $\$ 0.00$ & $\$ 0.00$ & $\$ 0.00$ & $\$ 0.00$ & $\$ 0.00$ & $\$ 0.00$ \\
\hline Operating Cost Contribution & $\$ /$ gge fuel & $\$ 1.38$ & $\$ 1.33$ & $\$ 1.17$ & $\$ 1.03$ & $\$ 1.17$ & $\$ 1.16$ & $\$ 1.06$ & $\$ 0.99$ & $\$ 0.92$ \\
\hline Feedstock Cost & $\$ /$ dry US ton & $\$ 106.92$ & $\$ 102.96$ & $\$ 90.57$ & $\$ 79.71$ & $\$ 102.12$ & $\$ 101.45$ & $\$ 92.36$ & $\$ 86.72$ & $\$ 80.00$ \\
\hline \multicolumn{11}{|l|}{ Fast Pyrolysis } \\
\hline Total Cost Contribution & $\$ /$ gge fuel & $\$ 0.97$ & $\$ 0.93$ & $\$ 0.91$ & $\$ 0.90$ & $\$ 0.78$ & $\$ 0.78$ & $\$ 0.77$ & $\$ 0.76$ & $\$ 0.76$ \\
\hline Capital Cost Contribution & $\$ /$ gge fuel & $\$ 0.82$ & $\$ 0.79$ & $\$ 0.76$ & $\$ 0.75$ & $\$ 0.66$ & $\$ 0.66$ & $\$ 0.65$ & $\$ 0.65$ & $\$ 0.64$ \\
\hline Operating Cost Contribution & $\$ /$ gge fuel & $\$ 0.15$ & $\$ 0.15$ & $\$ 0.15$ & $\$ 0.15$ & $\$ 0.12$ & $\$ 0.12$ & $\$ 0.12$ & $\$ 0.12$ & $\$ 0.11$ \\
\hline Pyrolysis Oil Yield (dry) & Ib organics/lb dry wood & 0.60 & 0.60 & 0.60 & 0.60 & 0.62 & 0.62 & 0.62 & 0.62 & 0.62 \\
\hline \multicolumn{11}{|c|}{ Upgrading to Stable Oil via Multi-Step Hydrodeoxygenation/Hydrocracking } \\
\hline Total Cost Contribution & $\$ /$ gge fuel & $\$ 10.07$ & $\$ 7.05$ & $\$ 5.23$ & $\$ 4.17$ & $\$ 2.88$ & $\$ 2.39$ & $\$ 2.01$ & $\$ 1.35$ & $\$ 0.95$ \\
\hline Capital Cost Contribution & $\$ /$ gge fuel & $\$ 0.71$ & $\$ 0.68$ & $\$ 0.66$ & $\$ 0.65$ & $\$ 0.59$ & $\$ 0.57$ & $\$ 0.51$ & $\$ 0.45$ & $\$ 0.42$ \\
\hline Operating Cost Contribution & $\$$ /gge fuel & $\$ 9.36$ & $\$ 6.37$ & $\$ 4.57$ & $\$ 3.52$ & $\$ 2.29$ & $\$ 1.82$ & $\$ 1.50$ & $\$ 0.90$ & $\$ 0.52$ \\
\hline $\begin{array}{l}\text { Annual Upgrading Catalyst Cost, } \\
\mathrm{mm} \$ / \text { year }\end{array}$ & \begin{tabular}{|l|} 
Annual cost is a function of: \\
$W^{\prime} \mathrm{SV}^{2}$, number of reactors, \\
catalyst replacement rate $\& \$ / \mathrm{lb}$
\end{tabular} & 512 & 344 & 243 & 184 & 130 & 100 & 80 & 43 & 19.4 \\
\hline $\begin{array}{l}\text { Upgraded Oil Carbon Efficiency on } \\
\text { Pyrolysis Oil }\end{array}$ & $\mathrm{w} t \%$ & $65 \%$ & $65 \%$ & $65 \%$ & $65 \%$ & $68 \%$ & $68 \%$ & $68 \%$ & $68 \%$ & $68 \%$ \\
\hline \multicolumn{11}{|c|}{ Fuel Finishing to Gasoline and Diesel via Hydrocracking and Distillation } \\
\hline Total Cost Contribution & $\$ /$ gge fuel & $\$ 0.25$ & $\$ 0.24$ & $\$ 0.24$ & $\$ 0.24$ & $\$ 0.25$ & $\$ 0.25$ & $\$ 0.24$ & $\$ 0.24$ & $\$ 0.14$ \\
\hline Capital Cost Contribution & $\$$ /gge fuel & $\$ 0.16$ & $\$ 0.15$ & $\$ 0.15$ & $\$ 0.15$ & $\$ 0.16$ & $\$ 0.16$ & $\$ 0.16$ & $\$ 0.16$ & $\$ 0.07$ \\
\hline Operating Cost Contribution & $\$$ /gge fuel & $\$ 0.09$ & $\$ 0.09$ & $\$ 0.09$ & $\$ 0.09$ & $\$ 0.09$ & $\$ 0.09$ & $\$ 0.08$ & $\$ 0.08$ & $\$ 0.07$ \\
\hline \multicolumn{11}{|l|}{ Balance of Plant } \\
\hline Total Cost Contribution & $\$$ /gge fuel & $\$ 0.74$ & $\$ 0.72$ & $\$ 0.71$ & $\$ 0.71$ & $\$ 0.68$ & $\$ 0.68$ & $\$ 0.67$ & $\$ 0.66$ & $\$ 0.63$ \\
\hline Capital Cost Contribution & $\$ /$ gge fuel & $\$ 0.36$ & $\$ 0.34$ & $\$ 0.33$ & $\$ 0.33$ & $\$ 0.29$ & $\$ 0.29$ & $\$ 0.29$ & $\$ 0.29$ & $\$ 0.29$ \\
\hline Operating Cost Contribution & $\$$ /gge fuel & $\$ 0.38$ & $\$ 0.38$ & $\$ 0.38$ & $\$ 0.38$ & $\$ 0.39$ & $\$ 0.38$ & $\$ 0.38$ & $\$ 0.37$ & $\$ 0.34$ \\
\hline Models: Case References & & $\begin{array}{c}2009 \text { SOT } \\
090913\end{array}$ & $\begin{array}{c}2010 \text { SOT } \\
090913\end{array}$ & $\begin{array}{c}2012 \text { SOT } \\
090913\end{array}$ & $\begin{array}{c}2012 \text { SOT } \\
090913\end{array}$ & $\begin{array}{c}2013 \text { SOT } \\
122013\end{array}$ & $\begin{array}{c}2014 \mathrm{P} \\
121913\end{array}$ & $\begin{array}{c}2015 P \\
123013\end{array}$ & $\begin{array}{c}2016 \mathrm{P} \\
121913\end{array}$ & $\begin{array}{l}2017 P \\
093013\end{array}$ \\
\hline
\end{tabular}

${ }^{1}$ Note: The table may contain very small $(\leq \$ 0.01)$ rounding errors due to the difference betw een the $w$ ay that Microsoft Excel ${ }^{T M}$ displays and calculates rounded values.

${ }^{2}$ WHSV is w eight hourly space velocity: w eight of oil feed per hour per w eight of catalyst. 


\subsection{Environmental Sustainability Metrics}

In addition to setting economic trajectories toward BETO Programmatic Goals for the conversion pathways included in the MYPP, BETO is evaluating the environmental performance of conversion pathways. The following environmental considerations are currently being assessed: greenhouse gas (GHG) emissions, fossil energy consumption, fuel yield, carbon-to-fuel efficiency, water consumption, and wastewater generation. Shown in Table 2 are the estimated metric values for the 2009, 2012, and 2013 SOT cases and the 2017 projected case for the fast pyrolysis and oil upgrading pathway. The cases shown align with the corresponding cost year scenarios presented in Table 1, the models for which are based on the 2013 design case (Jones et al 2013). Metrics for the 2010 and 2011 are not shown because they only differ from the 2009 and 2012 cases by catalyst lifetime, and therefore result in only slight changes in GHGs and fossil energy.

Table 2. Sustainability Metrics for Fast Pyrolysis and Upgrading Conversion

\begin{tabular}{|c|c|c|c|c|}
\hline Sustainability Metric & 2009 SOT $^{1}$ & 2012 SOT & 2013 SOT & 2017 Projected \\
\hline $\begin{array}{l}\text { GHGs ( } \mathrm{g} \mathrm{CO}_{2} \text {-e/MJ fuel) (fossil } \\
\text { emissions; biogenic emissions) }{ }^{2}\end{array}$ & $22.1 ; 104$ & $19.8 ; 104$ & $20.5 ; 85$ & $18.9 ; 85$ \\
\hline $\begin{array}{l}\text { Fossil Energy Consumption (MJ } \\
\text { fossil energy/MJ fuel) }{ }^{3}\end{array}$ & 0.326 & 0.294 & 0.321 & 0.301 \\
\hline $\begin{array}{l}\text { Total Fuel Yield (gal/dry ton wood; } \\
\text { gge/dry ton wood) }\end{array}$ & $74 ; 78$ & $74 ; 78$ & $84 ; 87$ & $84 ; 87$ \\
\hline $\begin{array}{l}\text { Carbon-to-Fuel Efficiency ( } \mathrm{C} \text { in } \\
\text { fuel/C in biomass) }\end{array}$ & $38 \%$ & $38 \%$ & $47 \%$ & $47 \%$ \\
\hline $\begin{array}{l}\text { Water Consumption }\left(\mathrm{m}^{3} / \text { day; }\right. \\
\text { gal/GGE fuel })^{4}\end{array}$ & $998 ; 1.5$ & $998 ; 1.5$ & $1124 ; 1.5$ & $1050 ; 1.4$ \\
\hline $\begin{array}{l}\text { Wastewater Generation }\left(\mathrm{m}^{3} / \text { day; }\right. \\
\text { gal/GGE fuel) }\end{array}$ & $917 ; 1.4$ & $917 ; 1.4$ & $948 ; 1.3$ & $932 ; 1.3$ \\
\hline
\end{tabular}

Table Notes:

1. The only difference between the 2009 and 2012 SOT cases is a decrease in hydrotreating catalyst consumption for the 2012 SOT.

2. Biogenic emissions include those contained in the char combustor exhaust, the waste heat from which is used for biomass drying.

3. Fossil energy consumption does not include grinding of the feedstock prior to the pyrolysis step.

4. Water consumption and wastewater generation include only direct use/emissions and do not include water associated with upstream production of materials and energy used at the plant.

5. Wastewater generation includes both wastewater from hydrotreating and blowdown from the cooling towers.

The metrics for GHG emissions and fossil energy consumption include both direct effects at the plant and upstream effects associated with the production and distribution of materials and energy for the plant operations, i.e., these are the life cycle emissions and energy usage for the conversion stage of the fuel supply chain. The SimaPro software (2011) is used to model and calculate cumulative GHGs and energy use for the conversion process. Mass and energy balance information from the process model, along with life cycle inventory data from the Ecoinvent (2011) and U.S. Life Cycle Inventory (2012) databases is used to populate the model. For a list of inventory data and additional assumptions, see Appendix A. Water consumption and wastewater generation values consider only direct water inputs and wastewater generation at the plant, and therefore do not include the effects of water use and discharge associated with production 
and distribution of energy and materials used at the plant. Water consumption and wastewater generation values consider only direct water inputs and wastewater generation at the plant.

\subsection{Overall State of Technology}

The 1440 hours presented above are currently the longest time on stream reported for upgrading conventional fast pyrolysis oil. Upgrading catalysis remains a significant technical challenge, but preliminary data being developed in $2014 \mathrm{R} \& \mathrm{D}$ programs are promising. In addition, BETO is supporting the demonstration of fast pyrolysis followed by upgrading with UOP's integrated biorefinery in Hawaii. UOP, in partnership with Ensyn, have formed Envergent and are currently deploying 400 metric tpd Rapid Thermal Processing ${ }^{\mathrm{TM}}$ units for combined heat and power applications, with a forward look toward transportation fuels (Envergent Technologies, 2011). Similarly Metso, in cooperation with UPM and VTT has built a $300 \mathrm{~kg} / \mathrm{h}$ fast pyrolysis plant fully integrated from the purchase and pretreatment of feedstock through bio oil production, transportation, storage, and end use (Lehto, 2009). This plant utilizes a fluidized bed boiler. Other bio oil efforts include research and development of catalytic fast pyrolysis by NREL, PNNL, Battelle Memorial Institute, UOP, KiOR, and VTT. This list is by no means exhaustive. Finally, numerous universities world-wide also play a significant role in the development of fast pyrolysis and catalytic fast pyrolysis. 


\subsection{References}

Cafferty, K., J. Jacobson, K. Kenney, E. Searcy, I. Bonner, G. Gresham, J. Hess, W. Smith, D. Thompson, V. Thompson, J. Tumuluru, N. Yancey. 2014. "Feedstock Supply System Design and Economics for Conversion of Lignocellulosic Biomass to Hydrocarbon Fuels, Conversion Pathway: Fast Pyrolysis and Hydrotreating Bio-oil Pathway, The 2017 Design Case". INL/EXT-14-31211. Idaho National Laboratory, Idaho Falls, ID. (unpublished)

EcoInvent Database (2011), Version 2.2, Hamburg, Germany: Swiss Center for Life Cycle Inventories.

Envergent Technologies (2011) Technology, FAQs: http://www.envergenttech.com/faq.php (accessed 15 April 2014)

Jones S.B., C. Valkenburg, C.W. Walton, D.C. Elliott, J.E. Holladay, D.J. Stevens, C. Kinchin, and S. Czernik. 2009. "Production of Gasoline and Diesel from Biomass via Fast Pyrolysis, Hydrotreating and Hydrocracking: A Design Case “. PNNL-18284 Rev. 1, Pacific Northwest National Laboratory, Richland, WA.

Jones, S., J. Male. 2012, "Production of gasoline and diesel from biomass via fast pyrolysis, hydrotreating and hydrocracking: 2011 state of technology and projections to 2017". PNNL-22133. Pacific Northwest National Laboratory, Richland, WA.

Jones, S.B., P. Meyer, L.Snowden-Swan, A. Padmaperuma, E. Tan, A. Dutta, J. Jacobson, K. Cafferty. 2013. "Process Design and Economics for the Conversion of Lignocellulosic Biomass to Hydrocarbon Fuels: Fast Pyrolysis and Hydrotreating Bio-Oil Pathway." PNNL-23053, NREL/TP-5100-61178. Pacific Northwest National Laboratory, Richland, WA.

Lehto, J., P. Jokela, Y. Solantausta, A. Oasmaa. 2009. "Integrated heat, electricity and bio-oil production. In: Bioenergy 2009 - Book of Proceedings, FINBIO publication 45, pp 915-922. ISBN 978-952-5135-44-2.

SimaPro Life Cycle Assessment Software, v. 7.3. Amersfoort, the Netherlands: Product Ecology Consultants, 2011.

U.S. Department of Energy. 2013. Biomass Multi-Year Program Plan. Office of the Biomass Program, Energy Efficiency and Renewable Energy, U.S. Department of Energy, Washington D.C.

U.S. Life Cycle Inventory Database.” (2012) National Renewable Energy Technology Laboratory, 2012. https://www.lcacommons.gov/nrel/search. 


\section{Appendix A - Methodology for GHG and Fossil Energy Calculations}

The life cycle modeling software, SimaPro, is used to model the conversion stage of the fuel life cycle. Table A. 1 lists the process inventory data used in SimaPro for GHG and energy estimates for the SOT and projected cases (see Table 2). The comments column gives additional parameters such as fuel heating values and further detail on the methodology. The inventory is based on material and energy balances from the process models. Data from the Ecoinvent database (2011) and the U.S. Life Cycle Inventory Database (2012) is used for estimating energy and emissions associated with the production and distribution of materials and energy used at the plant (natural gas, electricity, catalyst, maintenance chemicals) and with waste treatment/disposal. Emissions and energy consumption for the U.S. average grid mix of electricity is assumed. The IPCC 2007 GWP 100a V1.02 inventory method and the Cumulative Energy Demand V1.07 inventory method (both included in the SimaPro package) are used to calculate the cumulative GHG emissions and fossil energy use, respectively. Due to a lack of available data on catalyst manufacture, recycling and reclamation processes, this component is approximated with a zeolite product from the Ecoinvent database. 
Table A.1. Inventory Data for Conversion GHG and Energy Estimates

\begin{tabular}{|c|c|c|c|c|c|c|}
\hline & & 2009 SOT & 2012 SOT & 2013 SOT & 2017 Projected & \\
\hline Products & Units & \multicolumn{4}{|c|}{ Quantity } & Comments \\
\hline Gasoline & Btu/hr & 454500875.2 & 454500875.2 & 420538581.8 & 420214996.5 & \\
\hline Gasoline LHV & Btu/lb & 18530 & 18530 & 18940 & 18900 & \\
\hline Diesel & Btu/hr & 373358106.2 & 373358106.2 & 509575635.5 & 509220020.0 & \\
\hline Diesel LHV & Btu/lb & 17950 & 17950 & 17880 & 17930 & \\
\hline \multicolumn{7}{|l|}{ Resources } \\
\hline $\begin{array}{l}\text { Water, unspecified natural } \\
\text { origin } / \mathrm{kg}\end{array}$ & $\mathrm{lb} / \mathrm{hr}$ & 91668 & 91668 & 103235 & 96410 & Cooling makeup and boiler feedwater makeup \\
\hline Air & $\mathrm{lb} / \mathrm{hr}$ & 847000 & 847000 & 789400 & 785400 & Air for burners \\
\hline Energy, output, from gasoline & $\mathrm{Btu} / \mathrm{hr}$ & 827858981.5 & 827858981.5 & 930114217.3 & 929435016.6 & Gasoline and diesel LHV together \\
\hline \multicolumn{7}{|l|}{ Materials/fuels } \\
\hline $\begin{array}{l}\text { Natural gas, high pressure, at } \\
\text { consumer/RER WITH US } \\
\text { ELECTRICITY U }\end{array}$ & Btu & 107114960 & 107114960 & 161840067 & 161840067 & $\begin{array}{l}\text { NG for steam reforming. Calculated NG flowrate } \\
\text { and } \mathrm{HHV} \text { of } 23,120 \mathrm{Btu} / \mathrm{lb} \text { from ChemCad model }\end{array}$ \\
\hline $\begin{array}{l}\text { Electricity, medium voltage, at } \\
\text { grid/US WITH US ELECTRICITY } \\
\text { U }\end{array}$ & $\mathrm{MWh}$ & 11.50 & 11.50 & 10.96 & 9.79 & Includes power credit from steam export \\
\hline $\begin{array}{l}\text { Zeolite, powder, at plant/RER } \\
\text { WITH US ELECTRICITY U }\end{array}$ & $\mathrm{lb} / \mathrm{hr}$ & 13.4 & 13.4 & 134.0 & 14.0 & Placeholder for stabilizer catalyst \\
\hline $\begin{array}{l}\text { Zeolite, powder, at plant/RER } \\
\text { WITH US ELECTRICITY U }\end{array}$ & $\mathrm{lb} / \mathrm{hr}$ & 1645.6 & 576.0 & 400.0 & 54.9 & Placeholder for hydrotreating catalyst \\
\hline $\begin{array}{l}\text { Zeolite, powder, at plant/RER } \\
\text { WITH US ELECTRICITY U }\end{array}$ & $\mathrm{Ib} / \mathrm{hr}$ & 2.0 & 2.0 & 3.0 & 0.7 & Placeholder for hydrocracking catalyst \\
\hline $\begin{array}{l}\text { Zeolite, powder, at plant/RER } \\
\text { WITH US ELECTRICITY U }\end{array}$ & $\mathrm{lb} / \mathrm{hr}$ & 1.7 & 1.7 & 1.8 & 1.8 & $\begin{array}{l}\text { Placeholder for hydrogen plant catalyst. Estimates } \\
\text { from Matros Technologies Steam Reforming. } \\
\text { catalyst life } 3 \text { yr; density } 58 \mathrm{lb} / \mathrm{ft} 3 \text {, and scaling with } \\
\text { methane flow rate }\end{array}$ \\
\hline $\begin{array}{l}\text { Hydrochloric acid, } 30 \% \text { in } \mathrm{H} 2 \mathrm{O} \text {, } \\
\text { at plant/RER WITH US } \\
\text { ELECTRICITY U }\end{array}$ & $\mathrm{lb} / \mathrm{hr}$ & 0.19 & 0.19 & 0.19 & 0.19 & Boiler chemicals \\
\hline $\begin{array}{l}\text { Sulphite, at plant/RER WITH US } \\
\text { ELECTRICITY U }\end{array}$ & $\mathrm{lb} / \mathrm{hr}$ & 0.19 & 0.19 & 0.19 & 0.19 & See above \\
\hline $\begin{array}{l}\text { Sodium hydroxide, } 50 \% \text { in } \mathrm{H} 2 \mathrm{O} \text {, } \\
\text { production mix, at plant/RER } \\
\text { WITH US ELECTRICITY U }\end{array}$ & $\mathrm{lb} / \mathrm{hr}$ & 0.19 & 0.19 & 0.19 & 0.19 & See above \\
\hline $\begin{array}{l}\text { Chemicals inorganic, at } \\
\text { plant/GLO WITH US } \\
\text { ELECTRICITY U }\end{array}$ & $\mathrm{Ib} / \mathrm{hr}$ & 0.13 & 0.13 & 0.34 & 0.25 & Cooling system maintenance chemicals \\
\hline
\end{tabular}




\begin{tabular}{|c|c|c|c|c|c|c|}
\hline $\begin{array}{l}\text { Refinery/RER/I WITH US } \\
\text { ELECTRICITY U }\end{array}$ & $\mathrm{p} / \mathrm{hr}$ & 0.0000031 & 0.0000031 & 0.0000032 & 0.0000032 & $\begin{array}{l}\text { Equipment for bio-oil refinery. Scaled based on } \\
\text { conventional refinery of } 1 \text { million tonne crude } \\
\text { oil/year. }\end{array}$ \\
\hline $\begin{array}{l}\text { Thermochemical Conversion } \\
\text { Plant }\end{array}$ & $\mathrm{p} / \mathrm{hr}$ & 0.0000063 & 0.0000063 & 0.0000063 & 0.0000063 & $\begin{array}{l}\text { Equipment for pyrolysis oil plant. Based on NREL } \\
\text { thermochem ethanol plant ( } 2000 \text { MTPD) }\end{array}$ \\
\hline $\begin{array}{l}\text { Dimethyl sulfoxide, at plant/RER } \\
\text { WITH US ELECTRICITY U }\end{array}$ & $\mathrm{lb} / \mathrm{hr}$ & 60 & 60 & 50 & 50 & $\begin{array}{l}\text { Dimethyl sulfoxide used as proxy for dimethyl } \\
\text { sulfide, sulfiding agent used for hydrotreating } \\
\text { catalysts. Conservative estimate because more } \\
\text { processing is required than for dimethyl sulfide) }\end{array}$ \\
\hline \multicolumn{7}{|l|}{ Emissions to air } \\
\hline Carbon dioxide, fossil & $\mathrm{lb} / \mathrm{hr}$ & 12537.90 & 12537.90 & 18943.51 & 18943.51 & Emissions from steam reforming of NG \\
\hline Carbon dioxide, biogenic & $\mathrm{lb} / \mathrm{hr}$ & 199672.09 & 199672.09 & 183158.14 & 183598.68 & \\
\hline Water & $\mathrm{lb} / \mathrm{hr}$ & 124222.83 & 124222.83 & 120187.49 & 119679.01 & Dryer and burner exhausts \\
\hline Water & $\mathrm{lb} / \mathrm{hr}$ & 34027 & 34027 & 41533 & 36940 & Evaporation and drift from cooling towers. \\
\hline Hydrogen sulfide & $\mathrm{lb} / \mathrm{hr}$ & 14.66 & 14.66 & 12.54 & 12.29 & \\
\hline Sulfur dioxide & $\mathrm{lb} / \mathrm{hr}$ & 100.25 & 100.25 & 100.23 & 100.23 & \\
\hline Carbon monoxide & $\mathrm{lb} / \mathrm{hr}$ & 0.04 & 0.04 & 0.038 & 0.30 & \\
\hline Methane, biogenic & $\mathrm{lb} / \mathrm{hr}$ & 2.55 & 2.55 & 2.57 & 2.61 & Wastewater and reformer burner exhaust \\
\hline \multicolumn{7}{|l|}{ Waste to treatment } \\
\hline $\begin{array}{l}\text { Treatment, sewage, unpolluted, } \\
\text { to wastewater treatment, class } \\
\text { 3/CH WITH US ELECTRICITY U }\end{array}$ & $\mathrm{m} 3 / \mathrm{hr}$ & 38.2 & 38.2 & 39.5 & 38.8 & $\begin{array}{l}\text { From upgrading and blowdown. Assume boiler } \\
\text { blowdown is recycled to cooling system and } \\
\text { cooling blowdown goes to WWT. }\end{array}$ \\
\hline $\begin{array}{l}\text { Disposal, wood ash mixture, } \\
\text { pure, } 0 \% \text { water, to sanitary } \\
\text { landfill/CH WITH US } \\
\text { ELECTRICITY U }\end{array}$ & $\mathrm{lb} / \mathrm{hr}$ & 1975 & 1975 & 1975 & 1975 & Ash from fast pyrolysis \\
\hline
\end{tabular}




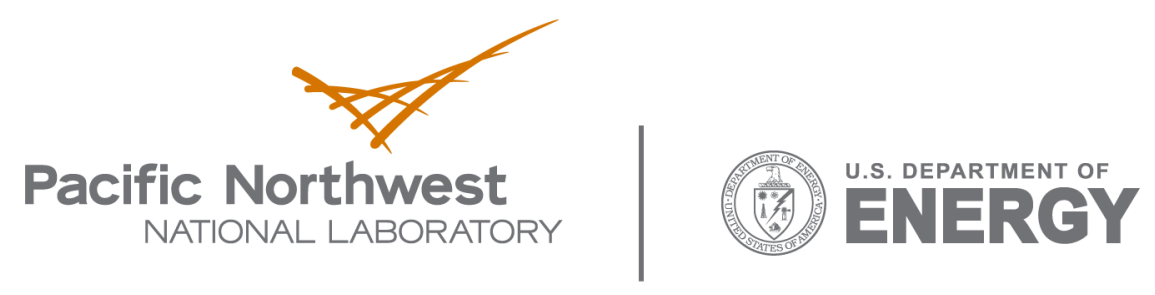

902 Battelle Boulevard

P.O. Box 999

Richland, WA 99352

1-888-375-PNNL (7665)

www.pnl.gov 